Karolina Piech

Uniwersytet Wrocławski

\title{
ZANIECHANIE OSOBY TRZECIEJ JAKO NEGATYWNA PRZESŁANKA OBIEKTYWNEGO PRZYPISANIA SKUTKU \\ - NA PRZYKŁADZIE ODPOWIEDZIALNOŚCI KARNEJ LEKARZA ZA BŁĄD MEDYCZNY
}

\section{WPROWADZENIE}

Problematyka związku przyczynowego nader często staje się przedmiotem orzecznictwa sądów karnych, zwłaszcza w sprawach medycznych. Jeszcze bardziej interesujący, zarówno dla doktryny, jak i judykatury, problem stanowi zagadnienie włączenia się do cudzego zakresu odpowiedzialności w postaci zaniechania osoby trzeciej, zaniechanie stanowi bowiem czyn powszechnie kryminalizowany nie tylko w polskim prawie karnym ${ }^{1}$. Szczególną uwagę przykuwa tutaj fragment wyroku Sądu Apelacyjnego w Katowicach: „Nie przerywa [...] związku przyczynowego między umyślnym działaniem oskarżonego w postaci silnego uderzenia w twarz pokrzywdzonego a nieumyślnym skutkiem w postaci śmierci pokrzywdzonego to, że po tym uderzeniu i upadku pokrzywdzonego na twarde podłoże nie podjęto w porę skutecznych zabiegów lekarskich, w następstwie czego udusił się on własną krwią, skoro i tak śmierć na skutek zachłyśnięcia się krwią była bezpośrednim

\footnotetext{
1 R. Кокот, O przestępnym i nieprzestępnym zaniechaniu udzielenia pomocy w niebezpieczeństwie w ujęciu kodeksu karnego z 1997 r., cz. II, «NKPK» 30/2013, s. 45.
} 
skutkiem obrażeń twarzoczaszki doznanych w wyniku wspomnianego uderzenia"2 - stwierdził Sąd Apelacyjny w Katowicach w wyroku z 6 kwietnia 2006 r. Cytowany fragment orzeczenia budzi jednak znaczne wątpliwości na gruncie nauki prawa karnego materialnego. Przedstawiciele doktryny stwierdzają co prawda, że zaniechanie wykonania zabiegu lekarskiego nie wpłynęło na przebieg przyczynowy prowadzący do śmierci pokrzywdzonego, podkreślają jednak, iż organ stosujący prawo „odnosił się w orzeczeniu do możliwości przypisania skutku w ogóle, uznając, że zaniechanie podjęcia zabiegów lekarskich nie miało wpływu na możliwość przypisania skutku oskarżonemu”3. Zauważyć bowiem należy, że pogląd wyrażony przez sąd orzekający w przedstawionej powyżej sprawie nie bierze pod uwagę zaistnienia negatywnej przesłanki obiektywnego przypisania skutku, jaką jest włączenie się do cudzego zakresu odpowiedzialności. Przesłanka ta aktualizuje się bowiem właśnie w takich sytuacjach, w których łańcuch przyczynowy przestępnych zachowań co prawda zostaje rozpoczęty przez potencjalnego sprawcę, jednakże do owego łańcucha kauzalnego włącza się osoba trzecia, która swoim zachowaniem (działaniem lub zaniechaniem) albo zwiększa ryzyko wywołane uprzednio przez potencjalnego sprawcę, albo stwarza nowe źródło ryzyka, które następnie urzeczywistnia się w jednym skutku przestępnym, albo też nie zapobiega wystąpieniu skutku przestępnego, mimo ciążących na niej obowiązków gwaranta. Zanim jednak rozpocznie się rozważania dotyczące zaniechania osoby trzeciej, która włącza się do rozpoczętego uprzednio przez inną osobę łańcucha kauzalnego, zauważyć należy, iż problem ten nader często aktualizuje się przy tzw. przestępstwach lekarskich, z którymi immanentnie wiąże się pojęcie błędu medycznego. Błąd medyczny - zwany również błędem lekarskim czy też błędem w sztuce lekarskiej - definiowany jest jako „naruszenie przez lekarza [...] reguł postępowania zawodowego wobec dóbr prawnych w postaci życia i zdrowia człowieka, które [...] stanowi

\footnotetext{
Wyrok SA w Katowicach z 6 kwietnia 2006 r., II AKa 89/06.

3 T. Sroka, Odpowiedzialność karna za niewłaściwe leczenie. Problematyka obiektywnego przypisania skutku, Warszawa 2013, s. 542.
} 
podstawę dla stwierdzenia naruszenia obowiązku ostrożności"4. Podkreślić przy tym należy z całą stanowczością, że owo naruszenie może mieć zarówno postać działania, jak i zaniechania ${ }^{5}$. Jako że świadczenia zdrowotne w wielu przypadkach podejmowane są w zespołach współdziałających osób lub sekwencyjnie, warto zadać pytanie, jaki jest status zaniechania włączającej się do łańcucha kauzalnego osoby trzeciej. Pokusić można się bowiem o stwierdzenie, że zaprezentowana przez sąd orzekający na gruncie wskazanego powyżej kazusu argumentacja jest nieprawidłowa, a zaniechanie - będąc jedną z postaci czynu - może mieć niebagatelny wpływ na zaistnienie lub brak ustawowo stypizowanego skutku i jego przypisanie sprawcy rozpoczynającemu swoim działaniem łańcuch kauzalny, a brak przyczynowości zaniechania nie ma w tym aspekcie większego znaczenia. Aby tezę tę udowodnić, warto odnieść się zarówno do dorobku doktryny prawa karnego materialnego, jak i do spraw będących niegdyś przedmiotem postępowań sądowych.

\section{ZANIECHANIE JAKO CZYN CZŁOWIEKA}

Dokonując analizy zagadnienia włączenia się do cudzego zakresu odpowiedzialności oraz zaniechania osoby trzeciej, można spotkać się w literaturze z poglądem, zgodnie z którym zaniechanie ma zupełnie inny wpływ na przebieg przyczynowy określonego zdarzenia ${ }^{6}$. Pogląd taki wyraził Mikołaj Małecki, stwierdzając, że: „brak interwencji gwaranta $\mathrm{w}$ zdarzenie nigdy nie jest w stanie zniweczyć czy nawet jedynie zmodyfikować rzeczywistego związku kauzalnego między pierwotnym działaniem innej osoby a urzeczywistniającym się w jego rezultacie niebezpieczeństwem dla dobra prawnego, zwieńczonym nastąpieniem

4 A. Liszewska, Odpowiedzialność karna lekarza za błąd w sztuce lekarskiej, Kraków 1998, s. 28.

5 A. Fiutak, Klasyfikacja błędów medycznych, «Medycyna Rodzinna» 2/2010, s. 51.

Należy mieć na uwadze, że zaniechanie nie będzie stanowić czynu karalnego w przypadku wyłączenia obowiązku np. z uwagi na niemożność działania; J. KulEszA, Granice obowiązku gwaranta w świetle art. 162 k.k., «Prok. i Pr.» 7-8/2006, s. 110. 
skutku opisanego w ustawie karnej"7. Pogląd ten autor argumentuje, wskazując, że zaniechanie nie jest przyczynowe, a jego istotą jest brak ingerencji człowieka w przebieg kauzalny określonego zdarzenia. $\mathrm{Na}$ takim stanowisku stoi również Sąd Najwyższy, który w jednym z orzeczeń stwierdza, że przesłanki obiektywnego przypisania skutku „różnią się w zależności od tego, czy chodzi o przestępstwo zrealizowane przez działanie czy zaniechanie"8.

Akceptując wprawdzie przytoczone wyżej opinie, nie można zgodzić się z faktem, że zaniechanie nie może prowadzić do wyłączenia odpowiedzialności karnej potencjalnego sprawcy, który swoim działaniem rozpoczyna określony przebieg kauzalny - zwłaszcza iż zaniechanie, tak samo jak działanie, stanowi jedną z postaci czynu. Autorzy niektórych z koncepcji co prawda zdecydowanie opowiadają się za poglądem, że zaniechanie nie jest postacią czynu, co najwyżej może stanowić „fikcję czynu”. Inne zaś traktują działanie i zaniechanie jako dwa różne aspekty jednego nadrzędnego pojęcia, jakim jest czyn. Zauważyć jednak należy, że wszelkie koncepcje odrzucające zaniechanie jako postać czynu zdają się stać w sprzeczności z normą zawartą w art. $115 \$ 1$ k.k. ${ }^{9}$, który stanowi, iż czynem zabronionym jest zachowanie o znamionach określonych w ustawie karnej. Nie budzi zatem wątpliwości, że ustawowa definicja czynu nie obejmuje wyłącznie działania. Co więcej - w doktrynie prawa karnego nie budzi już wątpliwości fakt, że zachowanie stanowić może zarówno działanie, jak i zaniechanie. Słusznie wskazuje bowiem Jan Kulesza: „Zarówno Konstytucja Rzeczypospolitej (art. 42 pkt 1), jak i Kodeks karny (por. np. art. $1 \$ 1$, art. 2, art. 5, art. 6 k.k.) przyjmują, że zaniechanie jest taką samą postacią czynu, jak działanie”10.

7 M. MаŁескі, Zbiegi i kolizje przypisania skutku, [w:] Obiektywne oraz subiektywne przypisanie odpowiedzialności karnej, red. J. GiezeK, P. Kardas, Warszawa 2016, s. 331.

8 Postanowienie SN z 9 maja 2013 r., V KK 324/12.

9 Ustawa z 6 czerwca 1997 r. - Kodeks karny (tekst jedn. Dz. U. z 2019 r. poz. 1950 ze $\mathrm{zm}$.).

10 J. Kulesza, O pojmowaniu zaniechania w polskiej nauce prawa karnego, „Czasopismo Prawa Karnego i Nauk Penalnych” 2/2007, s. 37. 
Akceptując, że zaniechanie stanowi jedną z postaci czynu, w doktrynie prawa karnego materialnego rozważano, czy zaniechanie może być przyczyną skutku, czy też nie może stanowić podstawy kauzalnej jego wystąpienia. Mikołaj Małecki stwierdza bowiem, że zaniechanie nie jest w stanie modyfikować przebiegu kauzalnego zdarzenia, wychodzi zatem z założenia, iż nie ma ono charakteru przyczynowego. W doktrynie prawa karnego materialnego takie poglądy oparte były początkowo na zasadzie ex nihilo nihil fit, zgodnie z którą - jak podkreśla Tomasz Kaczmarek - wskazywano, że „skoro z niczego nic nie powstaje, to należy przyjąć zatem [...], że zmiany w świecie zewnętrznym wywołać może jedynie aktywne zachowanie się człowieka, a zatem, że brak działania siłą konieczności pociągać musi nie przyczynowość, ale jej deficyt"11. Nie godząc się na takie ujęcie, wypracowano koncepcję przyczynowości zaniechania przez działanie inaczej, która jednakże spotkała się z powszechną krytyką w piśmiennictwie karnistycznym ${ }^{12}$. Następnie $\mathrm{w}$ doktrynie proponowano różnorakie koncepcje, zgodnie z którymi przyczynowość zaniechania uzasadniano na podstawie aktywnej postaci zachowania się podmiotu, który był sprawcą zaniechania. Dla przykładu - Otto Krug dowodził, że istota przyczynowości zaniechania tkwi w czynności owo zaniechanie poprzedzającej, która polega na podjęciu zobowiązania do wykonania określonego działania, co z kolei wzbudza przeświadczenie innych osób o tym, iż mogą one wszcząć dany przebieg przyczynowy, ponieważ nastąpić ma czynność zapobiegająca wystąpieniu negatywnego skutku. Konstrukcja taka jednak - oprócz tego, że stanowi swoiste „ominięcie” problemu przyczynowości zaniechania oraz zakłada, że de facto nie jest ono samoistną postacią czynu - wydaje

11 T. Kaczmarek, Spory wokół przyczynowości zaniechania i przypisywania jego skutku, [w:] Aktualne problemy prawa karnego. Ksiega pamiątkowa z okazji jubileuszu 70. urodzin Profesora Andrzeja J. Szwarca, Poznań 2009, s. 197.

12 Zgodnie $\mathrm{z}$ tą koncepcją zaniechanie stanowi równocześnie pozytywna czynność, ponieważ człowiek, który zaniechał jakiejś aktywności, w tym samym momencie wykonywać musiał inną pozytywną czynność, która staje się przyczyną stypizowanego w ustawie skutku. O. Krug poddał tę koncepcję ironicznej krytyce, posługując się przykładem matki powodującej śmierć głodową niemowlęcia poprzez zaniechanie na skutek robienia na drutach. 
się dość niefortunna. Odnosząc się do kazusu zaprezentowanego we wstępie niniejszego artykułu, trzeba byłoby stwierdzić, że dla przypisania skutku lekarzowi - gwarantowi konieczne byłoby ustalenie, iż sprawca wszczynający łańcuch kauzalny uderzył pokrzywdzonego, pozostając w przeświadczeniu, że negatywnemu skutkowi w porę zapobiegnie pracujący na oddziale ratunkowym lekarz. Koncepcje te były gorliwie krytykowane przez zwolenników tezy o obiektywnym bycie zaniechania. Przykładowo - Marian Cieślak stwierdził, że ich przyjęcie prowadzić musiałoby do stwierdzenia, że „dziura w bucie jest tylko brakiem skóry, a więc niczym, wobec czego nie istnieje, wobec czego but nie jest dziurawy"13. Podobne stanowisko zajmuje też Tomasz Kaczmarek: ,jak z braku tlenu w pomieszczeniu, w którym znalazł się człowiek, wyniknąć może dla niego bardzo wiele, [...], tak samo w sferze ludzkich zachowań z braku działania powstać mogą równie istotne następstwa, jak z podjętego działania"14. Opozycyjne stanowisko zaś obrazuje pogląd Władysława Mąciora, zgodnie z którym zaniechanie w świecie obiektywnym jest „zerem”, nie jest ani od strony subiektywnej, ani obiektywnej zjawiskiem realnym, stanowi natomiast „dający się pomyśleć brak oczekiwanej akcji”. Podobne stanowisko zajmuje Jacek Giezek, stwierdzając, że zaniechania nie można sprowadzić do płaszczyzny ontologicznej, gdyż jego spostrzeżenie możliwe jest dopiero po wyodrębnieniu płaszczyzny normatywnej, stanowiącej w tym przypadku nasze oczekiwania w stosunku do powinności ciążących na sprawcy ${ }^{15}$. Tezie o ontologicznej naturze zaniechania sprzeciwia się również Andrzej Zoll, uznając zaniechanie za bezczynność w „kierunku wyznaczonym przez prawo"16.

Zapytać należy jednak, czy stwierdzenie, że zaniechanie ma charakter obiektywny oraz przyczynowy albo że takiego charakteru nie posiada, ma jakikolwiek wpływ na rozstrzygnięcie sporu o możliwość pociągnięcia do odpowiedzialności karnej sprawcy, który zaniechał podjęcia

13 M. Cieślak, Polskie prawo karne, Warszawa 1994, s. 164.

14 T. KaCZMAReK, op. cit., s. 197.

15 Kodeks karny. Część ogólna. Komentarz, red. J. GiezeK, Warszawa 2012.

16 A. Zoll, Odpowiedzialność karna za niepowodzenie w leczeniu, Warszawa 1988, s. 48 . 
działania mającego zmierzać do zapobieżenia negatywnemu skutkowi oraz - co więcej - czy wyklucza możliwość zwolnienia z odpowiedzialności karnej osoby, która swoim działaniem dany łańcuch kauzalny rozpoczęła. Innymi słowy - czy we wskazanej na początku niniejszego artykułu sprawie sąd orzekający nie popełnił błędu, stwierdzając, że skoro zaniechanie nie posiada cechy przyczynowości, to nie może być mowy o wyłączeniu odpowiedzialności karnej sprawcy, który swoim działaniem pierwotnie stworzył zagrożenie dla dobra prawnego. Aby odpowiedzieć na tak postawione pytanie, należy bliżej przyjrzeć się wypracowanym na gruncie nauki prawa karnego negatywnym kryteriom przypisania skutku, zwłaszcza zaś przesłance tzw. włączenia się do cudzego zakresu odpowiedzialności - ona bowiem najpełniej odzwierciedla się w sprawie, która stała się przedmiotem orzeczenia sądu, cytowanego we wstępie niniejszego artykułu.

\section{KRYTERIA PRZYPISANIA SKUTKU PRZESTĘPNEGO ZANIECHANIA}

W celu rozwiązania wyżej wskazanego problemu warto zadać pytanie, do jakich kryteriów należy się odwołać, chcąc ocenić możliwość przypisania skutku osobie A, która swoim działaniem rozpoczyna określony łańcuch kauzalny, po czym do owego łańcucha kauzalnego włącza się swoim zaniechaniem osoba B, zwiększając stopień zagrożenia dla dobra prawnego, które następnie urzeczywistniło się w przestępnym skutku. Sytuacje takie bardzo często znajdują miejsce właśnie na płaszczyźnie tzw. lekarskiego prawa karnego, kiedy to - przykładowo - jeden z lekarzy na skutek błędu lekarskiego sprowadza zagrożenie dla życia pacjenta, po czym - kończąc dyżur - pozostawia go pod opieką swojego „kolegi po fachu”. Drugi z lekarzy z kolei, błędnie oceniając stan pacjenta jako dobry, nie podejmuje odpowiednich działań, czym zwiększa ryzyko wystąpienia skutku śmiertelnego, czy też - przy przyjęciu powszechnie aprobowanej $\mathrm{w}$ doktrynie tezy o braku przyczynowości zaniechania - nie zapobiega zwiększaniu się tego ryzyka samoistnie, po czym ów skutek następuje. Co oczywiste, proces oceny, kogo należy uznać za sprawcę określonego skutku, przebiegać musi dwuetapowo - po 
pierwsze, należy ustalić związek przyczynowy między działaniem osoby A a skutkiem, po drugie - stwierdzić należy, czy zaniechanie osoby B mogło temu skutkowi zapobiec. W związku z tym w doktrynie prawa karnego podzielono przesłanki obiektywnego przypisania skutku - na przesłanki pierwszego i drugiego stopnia, innymi słowy - przesłanki pozytywne oraz negatywne. Jak podkreśla Marek Bielski: „Istotą przesłanek negatywnych jest wypracowanie kryteriów pozwalających na weryfikowanie możliwości przypisania skutku pod kątem ustalenia kryminalnopolitycznej potrzeby pociągnięcia do odpowiedzialności karnej w sytuacjach, w których skutek przestępny nie był następstwem niebezpieczeństwa wynikającego tylko i wyłącznie $\mathrm{z}$ bezprawnego zachowania potencjalnego sprawcy, lecz był także determinowany obiektywnie nieprawidłowym zachowaniem innych osób"17. Zauważyć warto, że Piotr Kardas wskazał na istnienie takich negatywnych kryteriów obiektywnego przypisania, jak samonarażenie się pokrzywdzonego, przejęcie przez dysponenta dobra prawnego lub inną osobę ryzyka spowodowania skutku przestępnego, podział pracy w zespole czy też, wskazywane już wcześniej wielokrotnie, włączenie się do cudzego zakresu odpowiedzialności ${ }^{18}$.

Nie chcąc wdawać się w dyskusję na temat teorii związku przyczynowego i zasadności przyjęcia jednej z proponowanych w doktrynie koncepcji tegoż związku, warto bliżej przyjrzeć się zagadnieniu tzw. przyczynowości hipotetycznej oraz roli hipotetycznych powiązań kauzalnych, znajdujących zastosowanie nie tylko w ustalaniu związku przyczynowego między zachowaniem sprawcy a określonym skutkiem, ale przede wszystkim wskazywanych często jako jedno z kryteriów obiektywnego przypisania skutku, nazywanego często mianem zgodnego z prawem zachowania alternatywnego. Zgodnie z wyrażonym w doktrynie stanowiskiem wyłączenie możliwości przypisania skutku ma miejsce wtedy, gdy z prawdopodobieństwem graniczącym z pewnością

17 M. BIELSKI, O potrzebie teoretycznej, dogmatycznej i kryminalnopolitycznej refleksji nad negatywnymi przesłankami obiektywnego przypisania skutku przestępnego, [w:] Obiektywne oraz subiektywne..., s. 244.

18 P. KARDAS, $W$ poszukiwaniu tzw. negatywnych przesłanek obiektywnego przypisania, [w:] Obiektywne oraz subiektywne..., s. 171. 
skutek nastąpiłby w sytuacji zgodnego z prawem i obowiązującymi w danej dziedzinie ludzkiej aktywności regułami postępowania zachowania alternatywnego. Jak podkreśla J. Giezek, możliwość przypisania skutku powinna „odpaść” już wtedy, gdy w razie podjęcia przez sprawcę zachowania alternatywnego jego wystąpienie było możliwe - czyli jeśli hipotetycznej przyczynowości zgodnego z prawem zachowania alternatywnego nie dałoby się wykluczyć z prawdopodobieństwem, które zbliżałoby się do granic pewności ${ }^{19}$. Koncepcja ta może bez wątpienia znaleźć zastosowanie w przypadku przestępstw materialnych z zaniechania, również na gruncie zagadnienia włączenia się do cudzego zakresu odpowiedzialności. Zachowanie alternatywne stanowić będzie wówczas działanie zgodnie z przyjętymi z prawem oraz regułami postępowania w danej dziedzinie ludzkiej aktywności. Na gruncie kazusu wskazanego we wstępie niniejszego artykułu odpowiedzialność karna sprawcy dopuszczającego się pobicia powinna zostać wyłączona, jeżeli z prawdopodobieństwem graniczącym z pewnością podjęte przez lekarza hipotetycznie działanie (które w rzeczywistości zostało przezeń zaniechane) zapobiegłoby śmierci pokrzywdzonego. Jeżeli jednak stwierdzi się, że brak jest odpowiednio wysokiego stopnia prawdopodobieństwa, problem przypisania skutku śmiertelnego osobie A na nowo „ożywa”20.

W celu rozwiązania problemu rozgraniczenia sfery odpowiedzialności karnej osoby, która rozpoczęła łańcuch kauzalny zmierzający do wystąpienia przestępnego skutku, oraz osoby, która swoim działaniem zwiększyła ryzyko wystąpienia skutku lub też wbrew ciążącemu na niej obowiązkowi temu skutkowi nie zapobiegła, wypracowano w doktrynie prawa karnego materialnego wiele szczególnych przesłanek obiektywnego przypisania skutku, różniących się nieco od tzw. przesłanek ogólnych. Zagadnieniem tym zajął się między innymi Otto Triffterer, który jako rozwiązanie tego - niezmiernie ważnego również dla praktyki wymiaru sprawiedliwości - problemu, zaproponował kryterium tzw. związku ryzyka. Jak wskazuje Ryszard Dębski, koncepcja Triffterera

19 J. GIEZEK, Zgodne z prawem zachowanie alternatywne jako kryterium przypisania skutku, «Kwartalnik Prawa Publicznego» 4/2004, s. 58.

20 Ibidem. 
opierała się na uznaniu, że związek ryzyka „pomiędzy czynem pierwszego (potencjalnego - przyp. aut.) sprawcy a dalszymi szkodami, do których przyczyniły się wadliwe zachowania osób trzecich"21, istnieje, „o ile stan niebezpieczeństwa spowodowany czynem pierwszego sprawcy nadal utrzymuje się jako moment zwiększający ryzyko"22. A contrario - Triffterer podkreślał również, że w przypadku gdy wadliwe zachowanie osoby trzeciej ma charakter umyślny lub posiada przymiot „ciężkiej nieostrożności”, odrzucić należy związek ryzyka między czynem pierwszej osoby a negatywnym skutkiem. Warto zauważyć, że Triffterer posługiwał się pojęciem „zachowania”23, obejmującego zarówno działanie, jak i zaniechanie sprawcy czynu zabronionego. Z kolei w doktrynie niemieckiej zaproponowano kryterium tzw. odpowiedzialności własnej sprawcy czynu zabronionego, zgodnie z którą każdy odpowiedzialny jest wyłącznie za własne zachowanie, poza sferą jego odpowiedzialności pozostają konsekwencje zachowań innych osób, również w rozumieniu spowodowania skutku w przypadku przestępstw materialnych. Koncepcja ta ma jednak wadę - problematyczne wydaje się zastosowanie jej na gruncie przestępstw materialnych z zaniechania, zwłaszcza w przypadku przyjęcia przeważającej w doktrynie tezy o braku przyczynowości tejże postaci czynu sprawcy. Na szczególne uwzględnienie zasługuje teoria Clausa Roxina, którą Jacek Giezek przedstawił w sposób następujący: „Jeśli ktoś stworzył dla chronionego dobra prawnego niebezpieczeństwo, które się urzeczywistniło, a nie było uzasadnione dozwolonym ryzykiem, to przypisanie skutku i tak musi odpaść, jeśli przemawiają przeciwko niemu inne, wynikające z porządku prawnego względy" ${ }^{24}$.

${ }^{21}$ R. DęBSKI, O tzw. negatywnych przesłankach obiektywnego przypisania, [w:] Obiektywne oraz subiektywne..., s. 214.

22 Ibidem.

23 O. Triffterer, Österreichisches Strafrecht. Allgemeiner Teil, Wien-New York 1994, s. 144.

24 J. GIEZEK, Teorie związku przyczynowego oraz koncepcje obiektywnego przypisania, [w:] System Prawa Karnego, III: Nauka o przestępstwie. Zasady odpowiedzialności, Warszawa 2013, s. 324. 
Właśnie owa koncepcja C. Roxina ${ }^{25}$ znalazła szczególne miejsce w polskim piśmiennictwie karnistycznym, dając początek negatywnej przesłance obiektywnego przypisania, jaką jest kryterium kolizji odpowiedzialności za skutek. Jak podkreśla M. Bielski, kryterium to znajduje zastosowanie w sytuacji zaistnienia bezprawnych zachowań dwóch lub więcej osób, które są wobec siebie w pełni autonomiczne, ale mimo to każde z tych zachowań urzeczywistnia się w skutku przestępnym ${ }^{26}$. Ujmując tę kwestię nieco inaczej, można powiedzieć, że skutek stanowi wypadkową dwóch lub więcej zachowań co najmniej dwóch osób. Zastosowanie tej koncepcji na gruncie praktycznym może jednak prowadzić do wystąpienia licznych problemów, przede wszystkim w przypadku wystąpienia takiego układu sytuacyjnego, w którym ryzyko naruszenia dobra prawnego nie urzeczywistniłoby się w negatywnym skutku, gdyby nie miały miejsca przynajmniej dwa skumulowane zachowania różnych osób. Do jeszcze większych komplikacji doprowadzić może zaś sytuacja, w której bez co najmniej dwóch skumulowanych zachowań potencjalnych sprawców skutek przestępny miałby zupełnie inną postać niż ten, który w rzeczywistości wystąpił ${ }^{27}$.

W doktrynie prawa karnego materialnego dążono do wskazania przesłanek, które musiałby wyczerpywać czyn osoby trzeciej, aby można było uznać, że niweczy on możliwość przypisania skutku (a przynajmniej w ostatecznym jego kształcie) osobie, która rozpoczęła łańcuch kauzalny. Innymi słowy - poszukiwano odpowiedzi na pytanie, jakie warunki spełnić musi zachowanie osoby trzeciej, aby można było uznać je za negatywną przesłankę przypisania skutku potencjalnemu sprawcy, który jako pierwszy dopuścił się działania lub zaniechania sprzecznego $\mathrm{z}$ regułami postępowania $\mathrm{z}$ określonym dobrem prawnym. Koncepcję, zgodnie z którą pod pewnymi ściśle określonymi warunkami istnieje

25 Por. C. Roxin, Problematyka obiektywnego przypisania, [w:] Teoretyczne problemy odpowiedzialności karnej w polskim orazniemieckim prawie karnym. Materiały Polsko-Niemieckiego Sympozjum Prawa Karnego, Karpacz, maj 1990, red. T. Kaczmarek, Wrocław 1990.

26 M. BIELsKI, Obiektywne przypisanie skutku przestępnego w przypadku kolizji odpowiedzialności za skutek, «PiP» 60.10/2005, s. 81.

27 Ibidem. 
możliwość swego rodzaju „przeniesienia” odpowiedzialności karnej na osobę trzecią, zaproponował w doktrynie polskiego prawa karnego J. Giezek. Zgodnie z tą koncepcją zachowanie osoby trzeciej, która włącza się do danego łańcucha kauzalnego, spełniać musi następujące przesłanki:

1. osoba ta musi zachować się w sposób obiektywnie nieprawidłowy;

2. na osobie trzeciej ciążyć musi obowiązek uchylenia niebezpieczeństwa dla dobra prawnego;

3. obowiązek ciążący na osobie trzeciej winien być związany z ciążącymi na niej obowiązkami, na przykład z zawodem przez nią wykonywanym ${ }^{28}$.

\section{ZaNiECHANIE OSOBY TRZECIEJ JAKO WŁĄCZENIE SIĘ DO} CUDZEGO ZAKRESU ODPOWIEDZIALNOŚCI W ORZECZNICTWIE POLSKICH SĄDÓW KARNYCH

Możliwość przypisania skutku przestępnego osobie trzeciej, która zaniechała wykonania ciążącego na niej obowiązku, przez co niejako „nie przerwała” rozpoczętego przez inną osobę związku przyczynowego, najłatwiej zobrazować na przykładzie licznych stanów faktycznych, które stały się przedmiotem postępowań karnych. To właśnie bowiem na gruncie praktyki wymiaru sprawiedliwości najpełniej urzeczywistnia się szeroka gama modyfikacji łańcucha kauzalnego rozpoczętego przez potencjalnego sprawcę. Za przykład posłużą trzy, rzec można sztandarowe, orzeczenia, które powodują dość spory kłopot w praktyce orzeczniczej.

Pierwszym, zasługującym na uwagę stanem faktycznym, w którym urzeczywistniła się przedstawiona w niniejszym artykule sytuacja, jest sprawa, która stała się przedmiotem postępowania przed Sądem Apelacyjnym w Gdańsku ${ }^{29}$. Ujmując zwięźle stan faktyczny, wskazać można, że sprawcy, działając wspólnie i w porozumieniu, zadali pokrzywdzo-

28 J. Giezek, Teorie związku..., s. 329.

29 Wyrok SA w Gdańsku z 21 lipca 2016 r., II AKa 157/16. 
nemu co najmniej trzy ciosy pięścią w twarz, doprowadzając do jego upadku, który z kolei skutkował obrażeniami ciała w postaci krwotoków, krwiaków oraz obrzęku mózgu. Następnie pokrzywdzony trafił pod opiekę lekarską, jednakże lekarz zaniechał działania w postaci wykonania jakichkolwiek zabiegów medycznych, po czym pokrzywdzony zmarł. Sąd $a$ quo w procesie rozstrzygania zastosował dwie, znane w doktrynie, koncepcje związku przyczynowego i przypisania skutku: „koncepcję tradycyjną, prostą, opartą o zasadę ekwiwalencji, zgodnie z którą związku przyczynowego między czynem a skutkiem nie przerywa włączenie się do łańcucha przyczyn okoliczności od sprawcy niezależnych, jeżeli jednocześnie bezspornie ustalono, że działanie sprawcy było co najmniej jednym $\mathrm{z}$ warunków, bez których następstwo, skutek w postaci śmierci pokrzywdzonego, by nie nastąpiło” ${ }^{30}$ oraz „przeważającą w najnowszym orzecznictwie tendencję do bardziej rygorystycznego, zacieśniającego podejścia, zgodnie z teorią obiektywnego przypisania skutku, tj. wielowątkowego procesu dochodzenia do ustalenia i oceny zakresu odpowiedzialności karnej sprawcy w powiązaniu z zachowaniem gwaranta nienastąpienia skutku, zgodnie z którą w szczególności w sprawach medycznych na pierwszy plan wysuwa się tzw. włączenie cudzego zakresu odpowiedzialności; rozumie się przez to konieczność uwzględnienia w ocenie normatywnych warunków przypisania skutku potencjalnemu sprawcy przypadków przejęcia odpowiedzialności za skutek przestępny przez obiektywnie nieprawidłowo zachowującą się osobę trzecią, do której zakresu odpowiedzialności zawodowej należało uchylenie niebezpieczeństwa dla dobra prawnego" ${ }^{31}$. Zarówno sąd a quo, jak i sąd ad quem uznały, że nie jest możliwe przypisanie skutku w postaci spowodowania śmierci sprawcom, którzy dopuścili się pobicia pokrzywdzonego. W swojej argumentacji oba sądy odwołały się do dwóch podstawowych przesłanek wyłączających możliwość przypisania skutku śmiertelnego sprawcom rozpoczynającym łańcuch kauzalny odległości skutku w postaci śmierci pokrzywdzonego od zachowania sprawcy oraz analizy hipotetycznych przebiegów przyczynowych (tj.

\footnotetext{
30 Ibidem.

31 Ibidem.
} 
koncepcji zgodnego z prawem zachowania alternatywnego). Jak słusznie wskazał sąd ad quem: „związek przyczynowy między zachowaniem oskarżonego a skutkiem śmiertelnym jest tym bardziej odległy, że rzutuje na niego niewłaściwe zachowanie gwaranta, które z dużym prawdopodobieństwem mogło zapobiec skutkowi (ustalenia Sądu I instancji, iż w przypadku prawidłowego postępowania lekarza większe były szanse na przeżycie pokrzywdzonego niż na jego śmierć)"32. Sąd ad quem powołał się również na opinię biegłego sporządzoną do celów postępowania w pierwszej instancji, zgodnie $\mathrm{z}$ którą $\mathrm{w}$ przypadku prawidłowego postępowania lekarza szanse na przeżycie pokrzywdzonego zwiększyłyby się, stwierdził również, że: „Sąd Okręgowy na podstawie opinii biegłych prawidłowo ustalił, że w przypadku prawidłowego postępowania lekarza większe były szanse na przeżycie pokrzywdzonego niż na jego śmierć" ${ }^{33}$. Tym samym sąd dokonał zwięzłej analizy hipotetycznego łańcucha przyczynowego - gdyby lekarz w miejsce zaniechania podjął działanie lege artis (zgodne z zasadami sztuki lekarskiej), to prawdopodobieństwo uniknięcia negatywnego skutku byłoby co najmniej wysokie. Argumentację sądu należy we wskazanej sprawie uznać za co prawda nierozbudowaną, ale ze wszech miar słuszną.

W drugiej sprawie, której analiza znajdzie miejsce na gruncie niniejszego artykułu, będącej przedmiotem rozpoznania przez Sąd Apelacyjny w Poznaniu ${ }^{34}$, stan faktyczny kształtował się następująco: oskarżony kilkukrotnie godził swoją żonę nożem (w okolicę klatki piersiowej, okolicę bródkową i powierzchnię grzbietową lewej ręki), powodując obrażenia w postaci ran kłutych. Rana kłuta klatki piersiowej była przyczyną zewnętrznego i wewnętrznego krwawienia oraz niewydolności oddechowo-krążeniowej. Pokrzywdzoną przewieziono do szpitala, gdzie po upływie dwóch dni nastąpił zgon, a sam oskarżony został uznany za sprawcę przestępstwa zabójstwa. Jednakże powołana w postępowaniu biegła stwierdziła, że przyczynę zgonu stanowił „błąd w sztuce, popełniony przez lekarza i nieudzielenie [...] właściwej pomocy, oraz że pomoc

\footnotetext{
32 Ibidem.

33 Ibidem.

34 Wyrok SA w Poznaniu z 13 grudnia 2012 r., II AKa 256/12.
} 
ta mogła być jeszcze skuteczną w dniu 26 listopada 2011 roku”35 - opinia ta stanowiła również niejako główny punkt apelacji wniesionej przez obrońcę oskarżonego, będąc podstawą wniesienia zarzutu błędu w ustaleniach faktycznych, jakich miałby dopuścić się sąd a quo. Sąd ad quem jednakże utrzymał w mocy zaskarżony wyrok, stwierdzając przede wszystkim, że „zarówno orzecznictwo Sądu Najwyższego i sądów powszechnych, jak i zdecydowana większość nauki prawa karnego opowiada się za teorią obiektywną związku przyczynowego, która polega na tym, że działanie sprawcy jest jednym z warunków koniecznych, bez którego dany skutek w danym przypadku by nie nastąpił. Przyłączenie się do działania sprawcy innych jeszcze przyczyn nie wyłącza odpowiedzialności karnej za powstały skutek" "36. Sąd ad quem zdaje się zatem nie widzieć różnic między nauką o związku przyczynowym oraz nauką o obiektywnym przypisaniu skutku, które zarówno doktryna, jak i Sąd Najwyższy zdecydowanie od siebie oddziela. Krytycznie ocenić należy również samo posłużenie się teorią warunku sine qua non - słusznie bowiem wskazała Joanna Kalandyk: „Przedstawiciele doktryny niejednokrotnie wypowiadali się już na temat braku przydatności powyższej teorii dla ustalenia związku przyczynowego na gruncie prawa karnego. Zarzuca się jej przede wszystkim, iż w rzeczywistości nie bada powiązań przyczynowych między czynem a skutkiem, lecz służy ocenie wartości kauzalnej działań sprawczych i potwierdzeniu przyjętej już wcześniej tezy o powiązaniu przyczynowym" ${ }^{37}$. Stwierdzić można zatem, że sąd orzekający nie tyle popełnił błąd w analizie możliwości przypisania skutku w konkretnym przypadku, ile w ogóle jej zaniechał. Nie znalazła tu bowiem miejsca ani analiza hipotetycznych powiązań kauzalnych na wypadek podjęcia przez lekarza działania, ani rozważenie przejęcia przez lekarza, który dopuścił się zaniechania, odpowiedzialności za skutek śmiertelny. Zarówno sąd a quo, jak i sąd ad quem pominęły zatem zagadnienie włączenia się do cudzego zakresu odpowiedzial-

35 Ibidem.

36 Ibidem.

37 J. Kalandy , Glosa do wyroku Sądu Apelacyjnego w Poznaniu - II Wydział Karny z 13 grudnia 2012 r. (II AKa 256/12), «Czasopismo Prawa Karnego i Nauk Penalnych» 2/2014, s. 180. 
ności, jakoby w ogóle one nie istniało. Ocena możliwości przypisania przestępnego skutku osobie, która rozpoczęła łańcuch kauzalny, jak i osobie, która swoim zaniechaniem nie zapobiegła wystąpieniu tegoż skutku, powinna zaś przebiegać w sposób podobny do przedstawionego w poprzednim kazusie - opierać się na analizie hipotetycznego łańcucha kauzalnego i znaczenia działania alternatywnego, które mogło być podjęte przez lekarza. Sąd orzekający mógłby również odnieść się do przesłanki związku ryzyka oraz do koncepcji C. Roxina, aprobowanej przez polską naukę prawa karnego materialnego.

Odnosząc się do ostatniego już, analizowanego na gruncie niniejszej pracy, orzeczenia sądu (Sąd Najwyższy) ${ }^{38}$, przedstawić należy stan faktyczny zaistniały w omawianej sprawie: czterech sprawców, wspólnie i w porozumieniu, działając publicznie i bez powodu i okazując lekceważenie dla porządku prawnego, wzięło udział w pobiciu pokrzywdzonego, poprzez uderzanie pięściami i kopanie w głowę i inne okolice ciała, powodując powstanie u pokrzywdzonego licznych obrażeń ciała. Po udzieleniu pierwszej pomocy przez świadków zdarzenia i wezwaniu przez nich karetki, pokrzywdzony został przewieziony do szpitala, gdzie opatrzono obrażenia, jednakże nie wyraził on zgody na dalsze wykonywanie żadnych zabiegów leczniczych i został wypisany z placówki na własne żądanie. Stan zdrowia pokrzywdzonego w ciągu kolejnych dni pogarszał się jednak, wobec czego po raz kolejny wezwano do niego karetkę pogotowia. Podejmowane tym razem w szpitalu zabiegi lecznicze okazały się jednak bezskuteczne, a sam pokrzywdzony zmarł. Sprawa rozpoznawana była przez sądy obu instancji, następnie zaś - na skutek złożenia kasacji przez obrońcę oskarżonych - również przez Sąd Najwyższy, który kasację oddalił, stwierdzając, że „jeżeli oceniane działanie sprawcy uruchamiające dany przebieg kauzalny łączyło się ze sprowadzeniem bardzo znacznego ryzyka naruszenia dobra prawnego i stanowiło naruszenie w sposób rażący reguły postępowania $\mathrm{z}$ tym dobrem, to ewentualne późniejsze zaniechanie przez osobę będącą gwarantem nienastąpienia skutku działań, które miały przerwać uruchomiony przebieg przyczynowy i odwrócić zagrożenie dla dobra prawnego, nie zwolni

38 Postanowienie SN z 9 maja 2013 r., V KK 342/12. 
z odpowiedzialności za skutek osoby, która ten przebieg uruchomiła, ani też nie zmniejszy jej winy. Przy czym odpowiedzialność takiej osoby za skutek nie zwalnia od odpowiedzialności także gwaranta, który nie wykonał ciążącego na nim obowiązku"39. Omawiane orzeczenie dotyczy co prawda innego rodzaju negatywnej przesłanki obiektywnego przypisania skutku, jaką jest przyczynienie się pokrzywdzonego, jednakże - podobnie jak włączenie się do cudzego zakresu odpowiedzialności przez osobę trzecią - przesłanka ta również zalicza się do kategorii tzw. przejęcia odpowiedzialności za skutek przestępny oraz prowadzi do tożsamej właściwie analizy przebiegu przyczynowego i możliwości przypisania negatywnego skutku osobie, która swoim zachowaniem jako pierwsza naraża na niebezpieczeństwo dobro prawne pokrzywdzonego. Sąd Najwyższy tymczasem w omawianej sprawie wyraził następujący pogląd: „Nie można wykluczyć, że w zainicjowany przez sprawcę łańcuch kauzalny włączy się zachowanie innej osoby, w tym samego pokrzywdzonego. Takie współprzyczynienie się może (choć nie musi) prowadzić do zmniejszenia zakresu odpowiedzialności sprawcy przez zmniejszenie stopnia winy uzasadnione mniejszym zakresem społecznej szkodliwości czynu, jaki można było sprawcy w takiej sytuacji przypisać" ${ }^{40}$. Przede wszystkim podkreślić należy, że zagadnienie obiektywnego przypisania skutku stanowi pojęcie z zakresu znamion strony przedmiotowej danego typu czynu zabronionego, w procesie dokonywania prawnokarnej oceny zachowania sprawcy jest zatem brane pod uwagę na etapie wcześniejszym niż poziom społecznej szkodliwości, a co dopiero stopień winy sprawcy. Sąd Najwyższy natomiast zdawał się całkowicie nie dostrzegać, że w omawianym kazusie problem stanowiło to, czy osoby, które dopuściły się pobicia pokrzywdzonego, można w ogóle uznać za sprawców skutku śmiertelnego. Co więcej - błędne jest stwierdzenie sądu, zgodnie z którym nie można rozważać możliwości zwolnienia z odpowiedzialności karnej osoby rozpoczynającej swoim działaniem przebieg przyczynowy, jeśli osoba ta rażąco naruszyła regułę postępowania $\mathrm{z}$ określonym dobrem prawnym i przez to

\footnotetext{
39 Ibidem.

40 Ibidem.
} 
sprowadziła bardzo znaczne ryzyko jego naruszenia. Stwierdzenie takie bowiem z góry wyklucza analizę hipotetycznego łańcucha kauzalnego, można uznać również, że odrzuca stosowanie negatywnej przesłanki włączenia się do cudzego zakresu odpowiedzialności in genere. Podkreślić należy natomiast, że w przypadku zaniechania osoby trzeciej ocena możliwości pociągnięcia potencjalnego sprawcy do odpowiedzialności karnej przebiegać powinna dwuetapowo - poczynając od ustalenia kauzalnego związku między działaniem pierwszej osoby a skutkiem przestępnym, kończąc na analizie hipotetycznych powiązań kauzalnych, z uwzględnieniem tzw. zachowania alternatywnego. Rację ma bowiem Sąd Apelacyjny we Wrocławiu, który stwierdził, że „kauzalną podstawą przypisania przestępstwa skutkowego popełnionego przez zaniechanie [...] jest wyjaśnienie przyczynowe prawnie relewantnego skutku. Wymaga to udzielenia odpowiedzi na pytanie, dlaczego doszło do wystąpienia skutku, jaka była tego kauzalna przyczyna. Dopiero wtedy, gdy kwestia ta zostanie prawidłowo rozwiązana, jest możliwe przejście na płaszczyznę normatywną i udzielenie odpowiedzi na pytanie, czy sprawca, który wbrew ciążącemu na nim obowiązkowi zaniechał określonego działania, mógł zapobiec powstaniu skutku”ł1. Należy również zauważyć, że sąd orzekający starał się odnieść do przesłanki tzw. związku ryzyka, jednakże zrobił to w sposób błędny, z góry zakładając, iż późniejsze zaniechanie gwaranta nie może takiego związku osłabić. Stwierdzić również należy, że wszystkie podstawowe przesłanki przejęcia odpowiedzialności za skutek przestępny, tj. wystąpienie obiektywnie nieprawidłowego zachowania osoby trzeciej, na której ciążył prawny szczególny obowiązek podjęcia działania w związku z wykonywanymi czynnościami zawodowymi, w tym przypadku wystąpiły, sąd zatem powinien pokusić się o analizę hipotetycznego przebiegu przyczynowego, jaki wystąpiłby w razie podjęcia czynności leczniczych podczas pierwszego pobytu pacjenta w szpitalu. Jeżeli z analizy tej wynikłoby, że zabiegi lecznicze z dużym prawdopodobieństwem zapobiegłyby śmierci pacjenta, odpowiedzialność za skutek śmiertelny sprawców, którzy dopuścili się pobicia, winna zostać wyłączona.

${ }^{41}$ Wyrok SA we Wrocławiu z 6 kwietnia 2016 r., II AKa 67/16. 


\section{ZAKOŃCZENIE}

Przyjęcie założenia, że zaniechanie ma charakter przyczynowy mimo iż budzi liczne kontrowersje na gruncie doktryny prawa karnego materialnego i dla większości jej przedstawicieli jest nie do zaakceptowania - znacznie upraszczałoby proces dokonywania oceny możliwości wyłączenia odpowiedzialności karnej potencjalnego sprawcy, który swoim działaniem spowodował ryzyko naruszenia dobra prawnego, w sytuacji gdy osoba trzecia - gwarant - nie zapobiegła mającemu miejsce skutkowi przestępnemu. Pociąga ono bowiem za sobą immanentnie stwierdzenie, że zarówno działanie, jak i zaniechanie posiadają taką samą wartość kauzalną, ocenianą de facto w sposób zerojedynkowy. Jeżeli zatem uznamy, że obie postacie zachowania sprawcy cechują się takimi samymi przymiotami (są bytem obiektywnym i posiadają charakter przyczynowy), oceniać je będziemy przez pryzmat takich samych kryteriów obiektywnego przypisania skutku. Innymi słowy - nie będziemy czynić żadnego rozróżnienia między procesem dokonywania prawnokarnej oceny zachowania sprawcy, który swoim działaniem rozpoczął łańcuch kauzalny prowadzący w ostateczności do negatywnego skutku, a procesem ustalania możliwości pociągnięcia do tejże odpowiedzialności sprawcy - gwaranta, który zaniechał podjęcia ciążącego nań obowiązku, przez co nie zapobiegł danemu skutkowi.

Jednakże przyjęcie tezy o braku przyczynowości zaniechania - akceptowanej przez większość przedstawicieli polskiej doktryny prawa karnego materialnego, którzy ponadto uznają spór o kauzalność drugiej z postaci czynu za zupełnie jałowy - nie wyklucza możliwości uwolnienia od odpowiedzialności karnej osoby rozpoczynającej swoim działaniem łańcuch kauzalny, co więcej - nie wyklucza również takiej sytuacji, w której uznanie tejże osoby za sprawcę przestępnego skutku będzie niedopuszczalne. Gdyby miało tak być, problem tzw. włączenia się do cudzego zakresu odpowiedzialności przez osobę dopuszczającą się przestępnego zaniechania miałby charakter bezprzedmiotowy. Tym bardziej dziwi argumentacja sądu orzekającego we wskazanej na początku niniejszego artykułu sprawie, jak i innych sądów - w kazusach, które przedstawione zostały na gruncie niniejszej pracy. Sam fakt, że 
zaniechanie gwaranta nie może przerwać związku przyczynowego, nie oznacza jednocześnie, iż przejęcie przez niego odpowiedzialności za skutek przestępny nie jest w ogóle możliwe. Po pierwsze, w tym przypadku należy posłużyć się zagadnieniem przyczynowości oraz dorobkiem nauki prawa karnego z zakresu związku przyczynowo-skutkowego, przy czym przedmiotem dokonywanej przez sąd analizy winien być wówczas nie tylko występujący faktycznie łańcuch kauzalny, lecz także hipotetyczny przebieg przyczynowy. Po drugie, sądy orzekające zdają się nie zauważać, że w rozpatrywanych przez nie sprawach związek ryzyka uznać można za tak odległy, że pierwotnie stwarzające niebezpieczeństwo dla dobra prawnego działanie może ulec niejako „dezaktualizacji”. Po trzecie wreszcie, powołać należy się w tym przypadku na koncepcję odpowiedzialności własnej - która pociąga za sobą immanentnie stwierdzenie, że każdy osoba może odpowiadać tylko i wyłącznie za swoje czyny, a w odniesieniu do przestępstw materialnych - jedynie za następstwa własnych czynów.

\section{ZANIECHANIE OSOBY TRZECIEJ JAKO NEGATYWNA PRZESŁANKA OBIEKTYWNEGO PRZYPISANIA SKUTKU - NA PRZYKŁADZIE ODPOWIEDZIALNOŚCI KARNEJ LEKARZA ZA BŁĄD MEDYCZNY}

\section{Streszczenie}

Artykuł dotyczy odpowiedzialności karnej lekarza za błąd medyczny stanowiący zaniechanie wymaganego przez prawo działania. Autorka rozpatruje to zagadnienie z punktu widzenia problematyki negatywnych przesłanek obiektywnego przypisania skutku. Celem artykułu jest udzielenie odpowiedzi na pytanie, kiedy zaniechanie lekarza włączającego się do rozpoczętego wcześniej przez innego pracownika medycznego łańcucha kauzalnego stanowić będzie przesłankę wyłączenia odpowiedzialności karnej tego pracownika. W tymże celu autorka, opierając się na metodzie dogmatyczno-prawnej, dokona analizy dorobku doktryny prawa karnego materialnego oraz orzecznictwa polskich sądów karnych. Autorka rozważy również, czy stwierdzenie, że zaniechanie ma charakter przyczynowy lub że nie posiada cechy przyczynowości, ma istotny 
wpływ na możliwość wyłączenia odpowiedzialności karnej osoby, która jako pierwsza stwarza niebezpieczeństwo dla życia lub zdrowia pacjenta. Autorka, wskazując przesłanki wyłączenia odpowiedzialności takiej osoby, w zakończeniu udziela odpowiedzi na powyższe pytania.

Third Party Negligence as a Premise Preventing an Objective Attribution of Culpability: a Physician's Liability for a Medical Error

\section{Summary}

The article considers a physician's liability under Polish criminal law for a medical error due to breach of duty. I examine the issue from the point of view of the premises which hinder or prevent an objective attribution, my aim being to answer the question when negligence on the part of a physician who joins a causal chain initiated by another medical professional will constitute a condition for his exemption from criminal liability. I apply the legal doctrine method to review the doctrine of Polish substantive criminal law and the jurisprudence of Polish criminal courts, and consider whether the determination that the negligence was or was not causative makes a difference to the possibility of exempting the person who first endangered the patient's health or life from criminal liability. I enumerate the premises for the exemption of such a person from criminal liability, and conclude by giving an answer to the question put at the beginning of the article.

Słowa kluczowe: przypisanie skutku; związek przyczynowy; błąd medyczny; odpowiedzialność lekarza; zaniechanie.

Keywords: attribution of culpability; causal relationship; medical error; medical liability; negligence.

\section{Literatura}

BIELsкi M., Obiektywne przypisanie skutku przestępnego w przypadku kolizji odpowiedzialności za skutek, «PiP» 60.10/2005, s. 65-75.

Cieślak M., Polskie prawo karne, Warszawa 1994. 
Fiutak A., Klasyfikacja błędów medycznych, «Medycyna Rodzinna» 2/2010, s. $50-55$.

GiezeK J. (red.), Kodeks karny. Część ogólna. Komentarz, Warszawa 2012.

GiezeK J., Kardas P. (red.), Obiektywne oraz subiektywne przypisanie odpowiedzialności karnej, Warszawa 2016.

GiezeK J., Teorie związku przyczynowego oraz koncepcje obiektywnego przypisania, [w:] System Prawa Karnego, III: Nauka o przestępstwie. Zasady odpowiedzialności, red. R. DęBSKI, Warszawa 2013.

GIEZEK J., Zgodne z prawem zachowanie alternatywne jako kryterium przypisania skutku, «Kwartalnik Prawa Publicznego» 4/2004, s. 49-72.

KACZMAREK T., Spory wokót przyczynowości zaniechania i przypisywania jego skutku, [w:] Aktualne problemy prawa karnego. Księga pamiątkowa z okazji jubileuszu 70. urodzin Profesora Andrzeja J. Szwarca, Poznań 2009.

KaCzMareK T. (red.), Teoretyczne problemy odpowiedzialności karnej w polskim oraz niemieckim prawie karnym. Materiały Polsko-Niemieckiego Sympozjum Prawa Karnego, Karpacz, maj 1990, Wrocław 1990.

Kalandy J., Glosa do wyroku Sadu Apelacyjnego w Poznaniu - II Wydziat Karny z 13 grudnia 2012 r. (II AKa 256/12), «Czasopismo Prawa Karnego i Nauk Penalnych» 2/2014, s. 45-58.

Кокот R., O przestępnym i nieprzestępnym zaniechaniu udzielenia pomocy w niebezpieczeństwie w ujęciu kodeksu karnego z 1997 r., cz. II, «NKPK» 30/2013, s. 45-54.

Kulesza J., O pojmowaniu zaniechania w polskiej nauce prawa karnego, «Czasopismo Prawa Karnego i Nauk Penalnych» 2/2007, s. 19-52.

Kulesza J., Granice obowiązku gwaranta w świetle art. 162 k.k., «Prok. i Pr.» 7-8/2006, s.108-122.

Liszewska A., Odpowiedzialność karna lekarza za błąd w sztuce lekarskiej, Kraków 1998.

MAŁECKI M., Zbiegi i kolizje przypisania skutku, [w:] Obiektywne oraz subiektywne przypisanie odpowiedzialności karnej, red. J. GiezeK, P. Kardas, Warszawa 2016.

Sroka T., Odpowiedzialność karna za niewłaściwe leczenie. Problematyka obiektywnego przypisania skutku, Warszawa 2013.

Triffterer O., Österreichisches Strafrecht. Allgemeiner Teil, Wien-New York 1994.

Zoll A., Odpowiedzialność karna za niepowodzenie w leczeniu, Warszawa 1988. 